\title{
Remote detection of coral 'bleaching' using pulsed-laser fluorescence spectroscopy
}

\author{
J. T. Hardy ${ }^{1}$, F. E. Hoge ${ }^{2}$, J. K. Yungel ${ }^{3}$, R. E. Dodge ${ }^{4}$ \\ ${ }^{1}$ Regional and Global Environmental Studies Program, Western Washington University, MS-9079, Bellingham, \\ Washington 98225, USA \\ ${ }^{2}$ NASA Goddard Space Flight Center, Wallops Flight Facility, Building N-159, Wallops Island, Virginia 23337, USA \\ ${ }^{3}$ EG\&G Inc. Washington Analytical Services, Building N-159, Wallops Island, Virginia 23337, USA \\ ${ }^{4}$ Oceanographic Center, NOVA University, 8000 North Ocean Drive, Dania, Florida 33004, USA
}

\begin{abstract}
Despite their biological and economic importance coral reefs are increasingly threatened by human activities. Recently, 'bleaching' of reefs, i.e. loss of photosynthetic pigmentation, has occurred at numerous globally-distributed sites. A number of environmental stressors, including increased water temperature, can induce bleaching. Several investigators have suggested that the widespread occurrence of coral bleaching represents an early warning signal of global greenhouse warming. Regardless of the cause, the extent of coral bleaching, both regionally and globally, needs to be documented and monitored. We conducted laboratory studies to evaluate the potential of using remotely-sensed laser-induced fluorescence to monitor coral pigmentation. Five species of Caribbean corals were collected, transported to the laboratory, and maintained in aquaria. Coral samples were irradiated at either $532 \mathrm{~nm}$ or $337 \mathrm{~nm}$ with pulsed-laser light and spectral scans of fluorescence were collected at $1 \mathrm{~nm}$ intervals. Distinct chlorophyll fluorescence peaks at 685 and $740 \mathrm{~nm}$ were observed in all species examined. In corals exposed to temperature-induced stress, incipient changes in the fluorescence spectra could be detected prior to visible bleaching and coral death. Remotely-measured (aircraft or ship) laser-induced fluorescence provides a potentially useful tool for monitoring the pigmentation status of coral reefs. Field validation will be necessary, but our results suggest that it may be possible to distinguish bleaching, or even partial bleaching, over large geographical areas with sensitivity and rapidity.
\end{abstract}

\section{INTRODUCTION}

Coral reefs are a vital global resource. They provide a rich habitat for a great diversity of marine species. As natural breakwaters, fringing and barrier reefs protect shorelines from wave-induced erosion. Numerous species utilize the sheltered waters created by reefs as nursery grounds for their young. The tourism, recreation and fishing industries, and thus the economies of many nations, depend on the presence of thriving coral reefs. Despite their biological and economic importance, coral reefs worldwide are being increasingly threatened by human activities. Recently, coral death and extensive 'bleaching' of reefs have been reported from numerous globally-distributed areas.

Symbiotic algae (zooxanthellae) within the coral polyps constitute an important source of carbon for the animal's nutrition and are essential to the health and growth of many corals (Muscatine et al. 1981, 1984).
Bleaching results from either wholesale loss of zooxanthellae from the coral tissue or from a decrease in the pigment density within individual zooxanthellae themselves (Hoegh-Guldberg \& Smith 1989, Kleppel et al. 1989). A number of environmental stressors, both natural and anthropogenic, can induce bleaching (Brown \& Howard 1985). These include salinity reduction, prolonged darkness, local pollution-induced stress such as dredging or deforestation with subsequent nearshore siltation, industrial and sewage discharges, non-point source storm-water runoff, and oil spills. The health of coral reefs, as with other ecosystems, is closely tied to climate. Bleaching is induced by increased water temperature and has been linked to warm water El Niño Southern Oscillation (ENSO) events in the Pacific. A short term (several days) increase of 3 to $4^{\circ} \mathrm{C}$ or a longer term increase of only 1 to $2{ }^{\circ} \mathrm{C}$ above the normal summer maximum temperature can induce bleaching (see review in Jokiel \& Coles 1990). 
Sublethal effects of temperature stress on corals include depressed feeding responses, reduced reproductive rates, increased extrusion of zooxanthellae and mucus, a decrease in the photosynthesis/respiration ratio (Johannes 1975), and reduced skeletal growth (Coles \& Jokiel 1978, Goreau \& Macfarlane 1990). Bleached corals in the Caribbean were not able to complete gametogenesis during the reproductive season following bleaching (Szmant \& Gassman 1990). If stress is sublethal, corals can recover completely from bleaching and show no evidence of histological damage (Hayes \& Bush 1990). However, if bleaching persists or recurs frequently, the coral will die.

Several studies have suggested that the recent world-wide occurrence of coral bleaching may represent an early warning signal of global greenhouse warming (Williams \& Bunkley-Williams 1990, Hayes \& Goreau 1991). In addition, corals, like most marine organisms, are very sensitive to solar uitraviolet- $B$ radiation (Jokiel \& York 1984, Hardy \& Gucinski 1989). Global increases in ultraviolet radiation could adversely affect coral reefs by increasing their sensitivity to thermally-induced bleaching (Lesser et al. 1990). Recent mass bleaching of reef corals has been reported from Bermuda, Panama, the Galapagos Islands, the Caribbean, Florida Keys, Hawaii, Australia, southern Japan, Polynesi, and Indonesia. Regardless of the cause, the extent of coral bleaching, both regionally and globally, needs to be documented and monitored (D'Elia et al. 1991). As Grigg \& Dollar (1990) stated, 'One of the most important limitations in assessing the effects of stress on coral reefs is the general lack of quantitative data (spatial and temporal) covering both natural and man-induced impacts.'

Fluorescence provides a non-destructive tool for monitoring changes in photosynthetic pigments. Photosynthesis involves trapping of light energy by photosynthetic systems I and II (PS-I and PS-II). Part of the trapped energy decays within 1 to 2 ns emitting photons (fluorescence). Peaks in the action spectra of in vivo chlorophyll fluorescence are believed to relate to different forms of chlorophyll a (chl a) and different proportions of chl $a$ and chl $b$ within PS-I and PS-II (Govindjee et al. 1971). The exact location of fluorescence peaks differs between species, but prominent peaks are often found for PS-II at 683 to $687 \mathrm{~nm}$ (with a satellite peak at $740 \mathrm{~nm}$ ) and for PS-I at $720 \mathrm{~nm}$.

The technology may now exist to rapidly assess the bleaching of coral reefs over large geographic areas. Airborne oceanographic LIDAR (light detection and ranging) systems use a pulsed-laser from an aircraft to measure the fluorescence emitted by aquatic or terrestrial chlorophyll pigments along the aircraft's flight path. In the last decade ecological applications of airborne laser-induced fluorescence (ALIF) have greatly expanded. Biological studies have included quantification of offshore marine phytoplankton (Hoge \& Swift $1981,1983,1985)$, mapping of coastal and terrestrial vegetation (Hoge \& Swift 1983, Hoge et al. 1983) and assessment of environmental stress on terrestrial plant communities (Chappelle et al. 1984, Schmuck \& Lichtenthaler 1986). Zooxanthellae within the tissues of coral also exhibit pigment fluorescence when irradiated at wavelengths of $532 \mathrm{~nm}$ or less. In addition, many corals contain granules within the polyp tissues (separate from zooxanthellae) which fluoresce when irradiated with ultraviolet wavelengths (Mazel 1988, Logan et al. 1990).

We describe here laboratory results which suggest that remote (boat or aircraft platform) laser-induced fluorescence has great potential as a useful tool for monitoring and rapidly assessing the pigmentation of coral reefs over large regions.

\section{METHODS}

Individual coral colonies were collected between September 30 and October 16, 1991 from depths of 7 to $10 \mathrm{~m}$ near Fort Lauderdale, Florida, USA. Corals were transported live to the NASA, Goddard Space Flight Center, Wallops Flight Facility, Virginia, USA, using the dry perlite method (Bronikowski 1982, Logan et al. 1990). Within $24 \mathrm{~h}$ of collection corals were placed in 38 to $75 \mathrm{I}$ re-circulating seawater aquaria and maintained at a temperature of $27^{\circ} \mathrm{C}$ and a salinity of 30 ppt. The aquaria were continuously illuminated with cool-white fluorescent lamps at an intensity of about $100 \mu \mathrm{W}$ (spectrally-integrated from 400 to $750 \mathrm{~nm}$, measured with a United Detector Technology Model 40A). Water quality parameters ( $\mathrm{pH}$, ammonium and nitrite) were monitored daily and maintained at acceptable levels during the course of the experiments.

Within 1 to $30 \mathrm{~d}$ of collection fluorescence spectra were measured on samples of 7 coral species: Agaricia agaricites, Dichocoenia stokesi, Meandrina meandrites, Montastrea cavernosa, Siderastrea siderea, Solenastrea bournoni, and Stephanocoenia michelinii. For most species, plugs were cut from the corals using a drill press equipped with a $2 \mathrm{~cm}$ diameter hole saw. In the case of the more convoluted Meandrina meandrites a wedge, approximately $1 \times 3 \mathrm{~cm}$, was cut from the distal portion of the colony with a metal hack saw blade. The coral samples were immediately placed in quartz cuvettes containing seawater, irradiated with pulsed-laser light, and fluorescent emission spectra collected with a spectrofluorometer (Hoge et al. 1983) (Fig. 1). Scan times were generally about $1 \mathrm{~min}$.

Two different lasers were used in separate experiments to provide excitation wavelengths comparable 


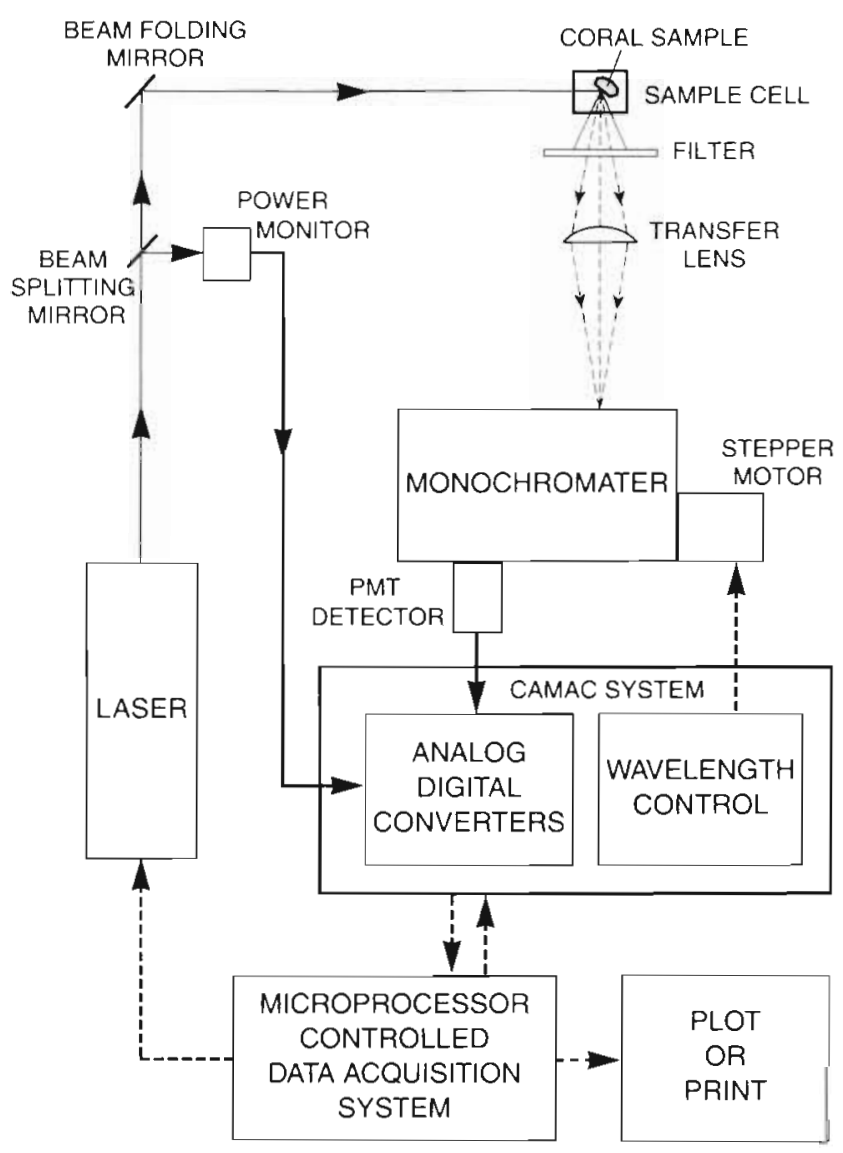

- ANALOG DATA

-...- DIGITAL DATA

Fig. 1 Configuration of laboratory pulsed-laser fluorescence spectrophotometer

to airborne LIDAR equipment. An International Laser Systems model NT274 frequency doubled Nd:YAG laser provided approximately $1.0 \mathrm{~mJ}, 532 \mathrm{~nm}$ excitation energy, and an Avco Everett model C-5000 nitrogen laser provided approximately $0.2 \mathrm{~mJ}, 337 \mathrm{~nm}$ excitation energy. Both laser pulse widths were approximately $15 \mathrm{~ns}$.

The laser radiation was directed into quartz cells holding the coral sample immersed in seawater. The resulting fluorescence was viewed normal to the incidence angle of the exciting laser radiation by an $\mathrm{f} / 3$ collection and transfer lens which provided optical matching to the Instruments SA model $\mathrm{H}-10 \quad 0.1 \mathrm{~m}$ Ebert configuration monochromater. In order to reject the strong scattering of laser radiation from the coral samples, longpass filters were placed between the sample and transfer lens. Filters consisted of a Schott Glass OG-550 for <550 nm (Nd:YAG laser), or a 2,7-dimethyl-3,6-diazacyclohepta-1,6-diene perchlorate liquid filter to reject radiation $<350 \mathrm{~nm}$ (nitrogen laser).
The grating of the monochromater was driven by a stepper motor through the CAMAC crate bus providing data system control of the grating in $0.5 \mathrm{~nm}$ steps. The output radiation from the monochromater was measured by a Hammamatsu R-666S photomultiplier tube (PMT), whose gain was controlled by an adjustable high voltage power supply. The output of the PMT was delayed to allow the gates triggered by the laser pulse to be generated, so that the gate pulse arrived simultaneously with the PMT output pulse, at the LeCroy model 2249SG charge digitizer. The gate pulse generated is approximately 50 ns wide allowing integration of resulting PMT output by the charge digitizer. The digital information from the charge digitizer is interfaced over the CAMAC crate data bus to the data collection system. The data collection software controls the grating steps and digitizer reading, allowing averaging of 30 pulses (nm step $)^{-1}$. Fluorescence spectral scans were collected at $1 \mathrm{~nm}$ intervals from 500 to $800 \mathrm{~nm}$ (Nd:YAG laser) or 300 to $800 \mathrm{~nm}$ (nitrogen laser). The resultant digital information was written to an ASCII data file, and plotted and analyzed using a standard MS-DOS spreadsheet program. Fluorescence values at all wavelengths were normalized to that at $600 \mathrm{~nm}$.

The effects of temperature-induced 'bleaching' on the fluorescence spectra within the same and among different coral species were examined. We maintained cuvettes, containing the coral samples, in aerated temperature-controlled seawater at $35^{\circ} \mathrm{C}$ under approximately the same illumination conditions as the aquaria (above) for $5 \mathrm{~d}$ and removed the cuvettes daily for spectral scans. Expelled pigments were rinsed from the cuvettes with clean seawater prior to performing scans. Duplicate cores of Solenastrea bournoni were maintained at $27^{\circ} \mathrm{C}$ as a control. Laser scans were also taken following an acute temperature exposure experiment. Samples of $S$. bournoni were exposed to a $35^{\circ} \mathrm{C}$ mean temperature for $4 \mathrm{~h}$ including a brief elevation to $40^{\circ} \mathrm{C}$ and then returned to $27^{\circ} \mathrm{C}$.

We also investigated an alternative method of measuring LIF of corals. A dual-cable fiber optic probe was placed directly over the coral colony with the probe head approximately $1 \mathrm{~cm}$ from the polyp tissue. Laser light was channeled through an excitation fiber cable to the probe head. An emission collection fiber cable in the probe head, oriented $90^{\circ}$ to the excitation cable, channeled the reflected light to the scanning monochromater.

Studies of marine phytoplankton (Hoge \& Swift 1981, 1983, 1985) and terrestrial plants (Hoge et al. 1983, Chappelle et al. 1984, Nelson et al. 1984) have applied different algorithms to remotely sensed color reflectance or fluorescence peaks in order to quantify chlorophyll pigments. For example, a curvature 

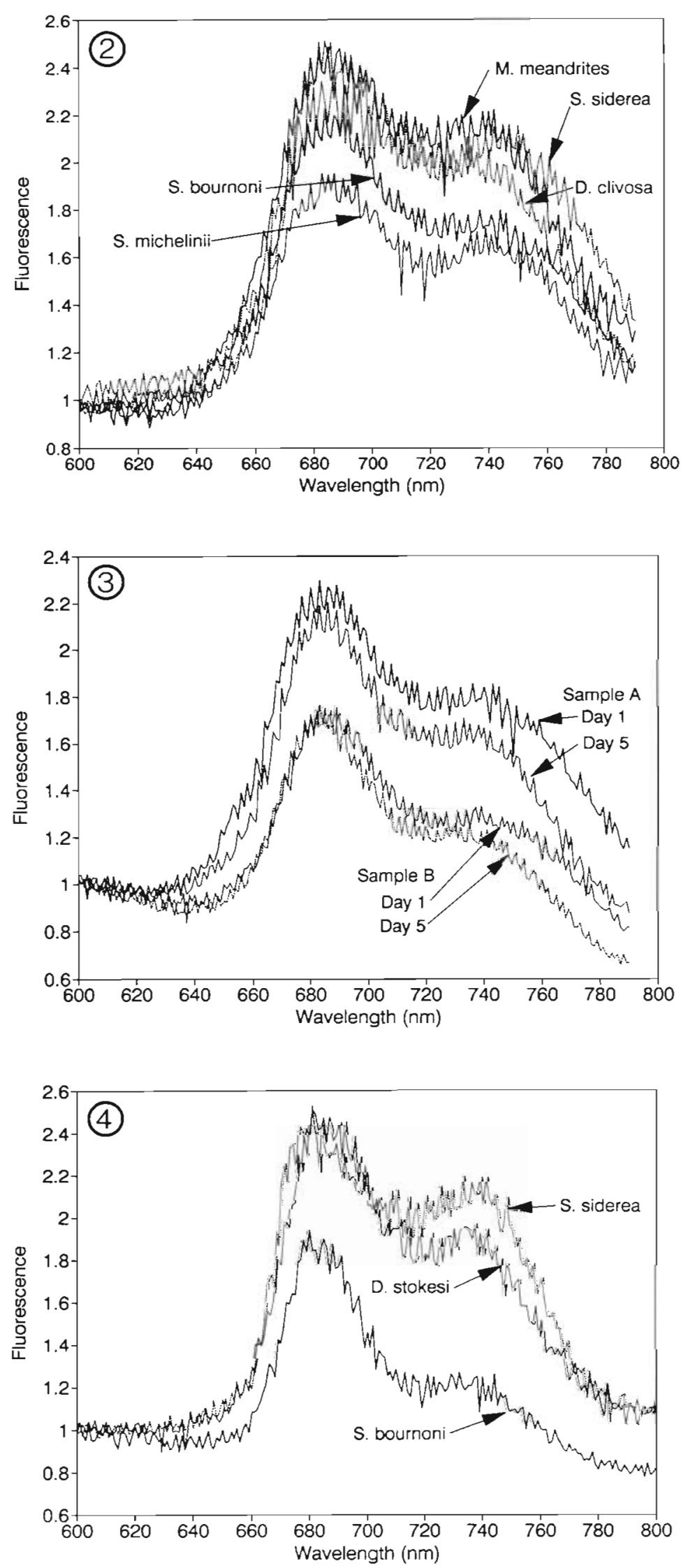

algorithm was effectively used for remote active-passive (laser-induced) correlation spectroscopy (Hoge \& Swift 1986). Here we apply a modified curvature algorithm to quantify LIF of corals, combining information contained in both the $685 \mathrm{~nm}$ and $740 \mathrm{~nm}$ peaks.

$$
C=\left(F_{685}\right)^{2} /\left(F_{715}\right)\left(F_{655}\right)+\left(F_{740}\right)^{2} /\left(F_{770}\right)\left(F_{710}\right)
$$

where $C=$ relative strength of chlorophyll fluorescence $F_{i}=$ fluorescence at wavelength $i$, normalized to $600 \mathrm{~nm}$.

Photosynthetic pigments were measured in samples of Solenastrea bournoni exposed to temperature stress. At 0,24 and $48 \mathrm{~h}$ of exposure to $35^{\circ} \mathrm{C}$, duplicate $2 \mathrm{~cm}$ diameter plugs were removed from the colony and ground with a mortar and pestle in $90 \%$ acetone. Spectral absorbance was measured using a Perkin Elmer Lambda 3B UV/Vis spectrophotometer following the procedures of Parsons et al. (1988). Pigment concentrations were expressed per unit surface area of coral.

\section{RESULTS}

\section{General similarity of species spectra}

All coral species, irradiated with a Nd:YAG laser at $532 \mathrm{~nm}$, demonstrated a remarkable similarity in fluorescence spectra (FS) (Fig. 2). In most species examined chlorophyll fluorescence peaks occurred consistently at about 685 and $740 \mathrm{~nm}$. FS of different samples of the same species differed in amplitude, probably due to different aspect angles and reflectance, and possibly different densities of zooxanthellae, but the shape of the FS did not differ between samples. FS decreased only slightly on cut samples removed from the colony and retained in cuvettes in an aquarium at $27^{\circ} \mathrm{C}$ for up to $5 \mathrm{~d}$ (Fig. 3 ).

Fig. 2. Fluorescence spectra of unstressed coral species, irradiated at $532 \mathrm{~nm}$. All 5 species show peaks at 685 and $740 \mathrm{~nm}$

Fig. 3. Solenastrea bournoni. When plugs were removed from 2 different colonies (A \& B) of coral and maintained at $27^{\circ} \mathrm{C}$, the fluorescence spectrum degraded only slightly after $5 \mathrm{~d}$

Fig. 4. Fluorescence spectra of 3 coral species irradiated at $532 \mathrm{~nm}$ using a dual fiber optic probe 
The fiber-optic probe placed, non-destructively, directly over the live coral colony proved equally effective at recording FS of corals (Fig. 4). The normal $685 \mathrm{~nm}$ peak was shifted toward $680 \mathrm{~nm}$, perhaps as a result of transmission through the optic fibers. Variations in the fluorescence strength over the surface of the coral could be 'mapped' as the probe was moved from one area of the colony to another.

The endolithic alga (perhaps a blue-green alga) within the skeletons of Montastrea cavernosa and Agaricea agaricites was also examined. When samples from inside $11 \mathrm{~cm}$ or deeper) the skeleton were irradiated the alga emitted a spectrum quite different from that of the intact live coral on the surface of the colony. The LIF spectra showed a broad peak with a maximum between 720 and $730 \mathrm{~nm}$ (Fig. 5).

Solenastrea bournoni, irradiated with the nitrogen laser at $337 \mathrm{~nm}$, demonstrated a broad fluorescence band from about 350 to $550 \mathrm{~nm}$ along with the typical chlorophyll fluorescence peaks at 685 and $740 \mathrm{~nm}$ (Fig. 6). The apparent peak at $495 \mathrm{~nm}$ is due to uncorrected blaze angle inefficiencies in the reflection grating of the monochromater.

\section{Eifects of temperature stress}

When Solenastrea bournoni was subjected to an acute temperature stress of 35 to $40^{\circ} \mathrm{C}$ over a $4 \mathrm{~h}$ period and then returned to $27^{\circ} \mathrm{C}$, the amplitude of the FS decreased over the following 6 d period (Fig. 7). Likewise, when other species were held constantly at $35^{\circ} \mathrm{C}$. the FS decreased over a $5 \mathrm{~d}$ period as the coral 'bleached' and eventually died (Fig. 8a, b, c).

Although peak heights of fluorescence differed somewhat between coral species, the

Fig. 5. Fluorescence spectra of endolithic alga irradiated at $532 \mathrm{~nm}$

Fig. 6. Solenastrea bournoni, irradiated with a nitrogen laser at $337 \mathrm{~nm}$, showed a broad fluorescence peak centered around $425 \mathrm{~nm}$ and chlorophyll peaks between 660 and $750 \mathrm{~nm}$

Fig. 7 Solenastrea bournoni. Fluorescence spectrum of coral declines with time following acute temperature stress. $C$ : computed curvature algorithm
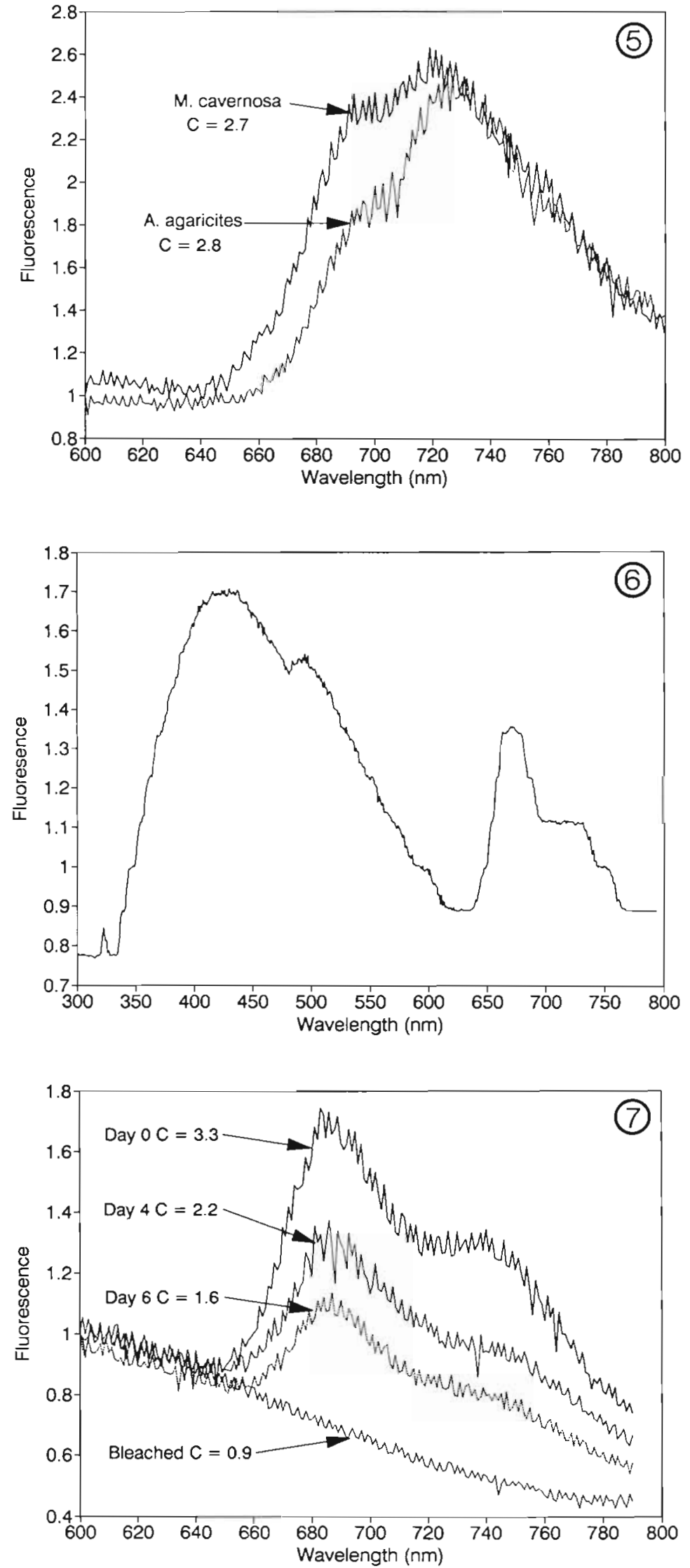

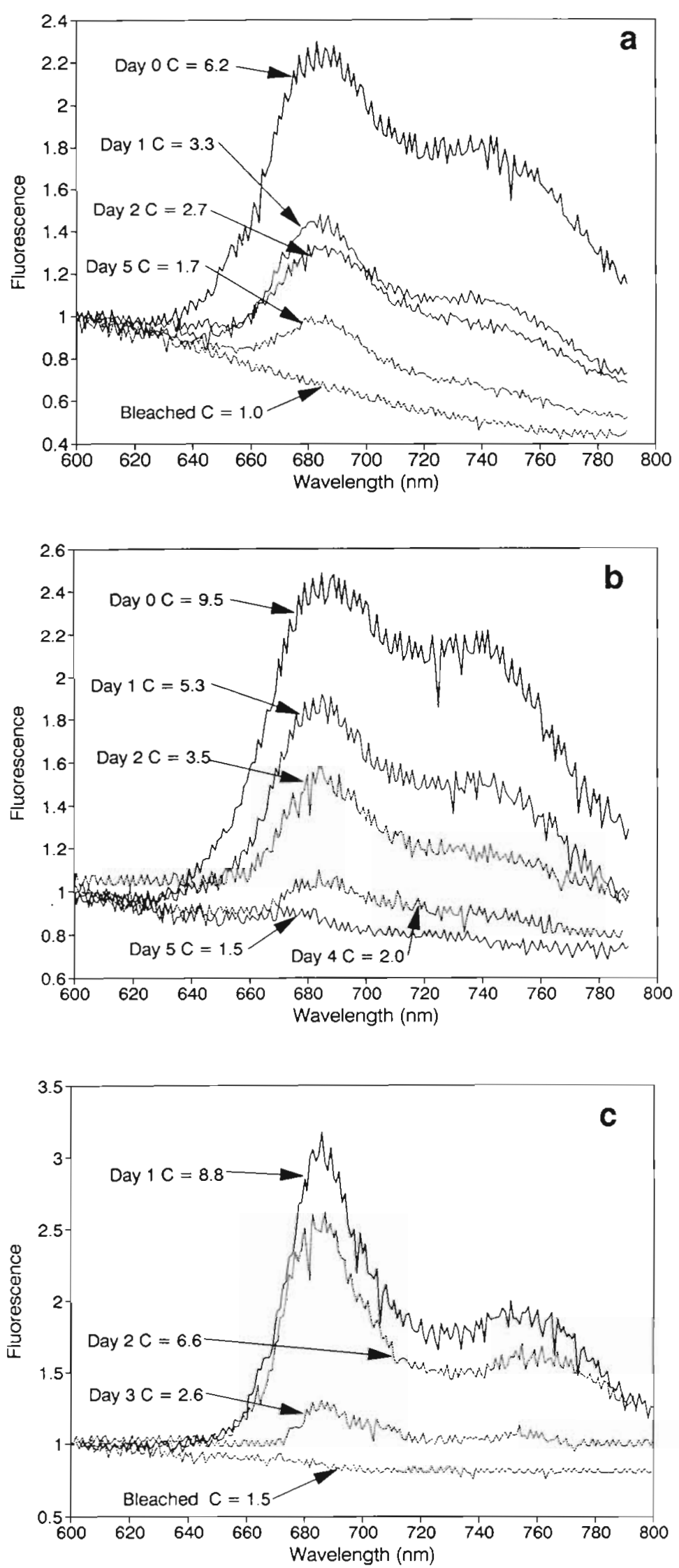

curvature algorithm $C$ varied by only $\pm 1.6 \%$ between species (Fig. 2). C also served as a sensitive indicator of the decline in the chlorophyll fluorescence. In normal corals $C$ was generally $>6$. In temperature-stressed coral $C$ declined over a period of $5 \mathrm{~d}$ to values of about 1 or less (Fig. 8a, b, c).

Extracted pigments of Solenastrea bournoni showed distinct chlorophyll $(665$ $\mathrm{nm}$ ) and carotenoid (480 nm) absorption peaks which decreased after exposure of the coral to elevated temperature $\left(35^{\circ} \mathrm{C}\right)$ stress (Fig. 9). During $48 \mathrm{~h}$ of temperature stress the quantity of chl $a, b, c$ and carotenoids declined by $55,47,87$, and $54 \%$, respectively (Fig. 10).

\section{DISCUSSION}

To our knowledge, these results represent the first recorded spectral scans of active laser-induced fluorescence in corals. Water column profiles of laser-induced phytoplankton pigment fluorescence spectra have been collected using a shipboard argon laser connected to a fiber-optic probe (Cowles et al. 1989, 1990). Passive (solarinduced) fluorescence has been measured in corals using a single band-pass filter (683 $\mathrm{nm}$ centered) fluorometer (Morrow et al. 1991). However, passive single-band fluorescence provides only a crude measure of coral pigment composition. Our approach, using scans over a wide spectral range, promises greatly increased sensitivity. The computation of curvature algorithms for different peaks should allow detection of subtle changes in coral pigments induced by environmental stress.

Bleached coral samples from the field have been found to contain greatly reduced quantities of photosynthetic pigments (Kleppel et al. 1989). In Florida, chl $C_{1}$ peridinin, and diadinoxanthin levels were 35,17 , and 20 times higher in normal corals than in bleached ones (Kleppel et al. 1989). In our experiments, before bleaching, the density of

Fig. 8. Fluorescence spectra of (a) Solenastrea bournoni, (b) Meandrina meandrites and (c) Siderastrea siderea declines during continuous temperature stress $\left(35^{\circ} \mathrm{C}\right)$. C: computed curvature algorithm 
Fig. 9. Solenastrea bournoni. Absorption spectra of acetone extract of pigments of temperaturestressed and unstressed coral

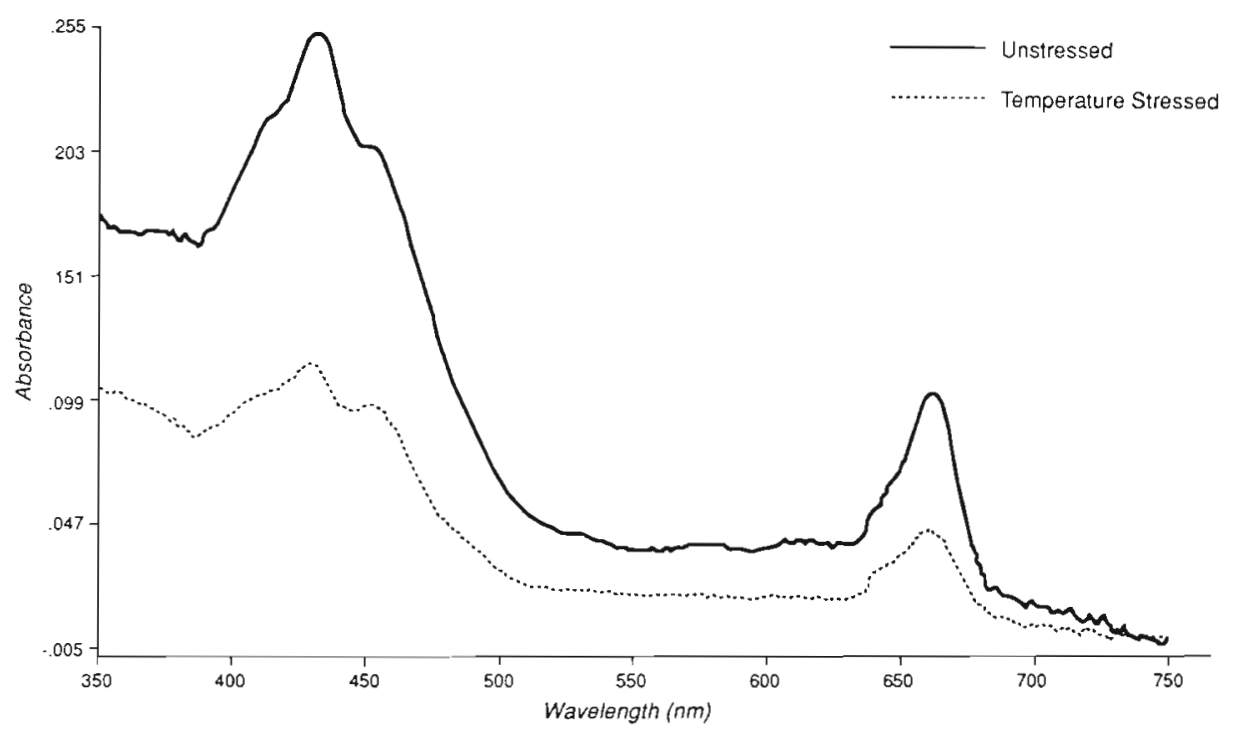

pigment $\left(\mu \mathrm{g} \mathrm{cm}^{-2}\right)$ over the surface of Solenastrea bournoni was about half that reported for Montastrea annularis from Florida (Kleppel et al. 1989). During our temperature-induced stress experiments both LIF and pigment concentrations in $S$. bournoni declined.

Our results show clear and dramatic changes in active fluorescence spectra of corals due to temperature stress. The mean temperature maximum over the past $50 \mathrm{yr}$ at Miami Beach, Florida, is about $31^{\circ} \mathrm{C}$. In this study, exposure of corals to a temperature $4{ }^{\circ} \mathrm{C}$ greater than this summer maximum resulted in bleaching and death. Our results do not differentiate clearly whether the pigment loss was due to chlorophyll degradation or to expulsion of zooxanthellae. However, masses of pigment sug-

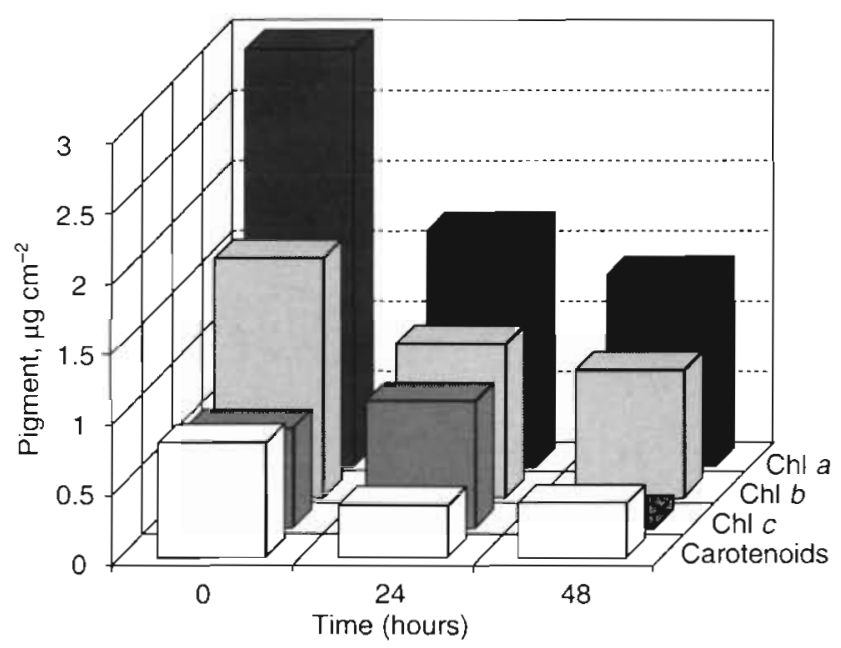

Fig. 10. Solenastrea bournoni. Decrease in photosynthetic pigments of coral exposed to elevated temperature of $35^{\circ} \mathrm{C}$ for $48 \mathrm{~h}$ gestive of expelled zooxanthellae were visible in the stressed samples. Further study is needed (possibly using cultured zooxanthellae) to examine possible changes in pigmentation and FS resulting from chronic exposure to smaller temperature elevations.

Can LIF measurements from remote platforms (aircraft or boats) be used to measure the pigmentation of coral reefs? Our laboratory results indicate strong fluoresence signals when corals are irradiated at 337 or $532 \mathrm{~nm}$. The NASA airborne laser (Hoge 1986) can penetrate to $30 \mathrm{~m}$ in clear oceanic waters. Phytoplankton pigments in the water column pose a potential source of interference. However, phytoplankton chl a densities in tropical waters are often less than $0.5 \mathrm{mg} \mathrm{m}^{-3}$ (Behrenfeld et al. 1992). In a $10 \mathrm{~m}$ water column this is equivalent to less than $0.5 \mu \mathrm{g} \mathrm{chl} \mathrm{a} \mathrm{cm} \mathrm{cm}^{-2}$. $\mathrm{Chl}$ a densities of coral colonies are likely to be about $3 \mu \mathrm{g} \mathrm{cm}^{-2}$ (this study) to $6 \mu \mathrm{g} \mathrm{cm}^{-2}$ (Kleppel et al. 1989). It is likely, therefore, that the high pigment densities of corals would produce a $680 \mathrm{~nm}$ fluorescence signal significantly stronger than the overlying phytoplankton, at least at depths down to $10 \mathrm{~m}$. In any case, a nanosecond pulsed LIDAR system will detect 2 signals, the first from the water surface and the second from the bottom. The instrument can be time (depth) 'gated' to detect fluorescence only from the bottom (coral) surface and to ignore the water column (phytoplankton) signal.

Overflights of airborne LIF sensors offer the potential advantage of covering large areas rapidly, but pose a problem of scale and resolution. At an overflight speed of $100 \mathrm{~m} \mathrm{~s}^{-1}$ and 20 pulses (samples) $\mathrm{s}^{-1}$, 1 fluoresence measurement (sample) would be collected about every $5 \mathrm{~m}$. Several overflights might be necessary to adequately characterize the pigmen- 
tation of a coral reef. Also, the longer-wavelength $740 \mathrm{~nm}$ fluoresence signal could be significantly attenuated by the water column.

Such difficulties could be overcome by the use of the fiber optic probe technique demonstrated in this study. This probe could allow selective assessment of individual corals using SCUBA as well as scanning from boats along transects at a fixed distance from the bottom.

We have reported on fluorescence of chlorophyll pigments within the zooxanthellae of corals. Many coral species also exhibit fluorescence when irradiated with ultraviolet light in vivo. Such UV fluorescence is the product of small granules in the epidermis or gastrodermis of the polyp animal itself (Mazel 1988, Logan et al. 1990). It has been hypothesized that fluorescence from these granules may act as a filter for harmful solar ultraviolet, converting it to longer wavelengths useful for photosynthesis by the zooxanthellae (Kawaguti 1969).

The broad-band fluorescence peak from 350 to 550 $\mathrm{nm}$, resulting from $337 \mathrm{~nm}$ excitation (nitrogen laser), may result from the accessory pigments carotene peridinin, dinoxanthin and diadinoxanthin known to be present in zooxanthellae (Taylor 1967). Further examination of this band could clarify its origin and usefulness as an environmental indicator.

Our laboratory results suggest that remote (ship or aircraft) active laser systems represent potentially powerful tools for coral reef research. Systems such as the NASA AOL would allow remote detection of pulsed laser-induced pigment fluorescence from coral, along with simultaneous measurement of passive solar-induced upwelled radiance, sea surface temperature and very accurate bathymetry. The acquisition of airborne upwelled radiances should allow more optimum selection of appropriate satellite bands and development of attendant algorithms. It should be possible to distinguish areas of coral reef bleaching, or even partial bleaching, with greater sensitivity than direct visual observation. In addition, of course, there is the advantage, using aircraft, of covering large areas rapidly, i.e. about 4 miles of reef per minute.

Acknowledgements. Partial support for this study was provided through the National Aeronautics and Space Administration Joint Venture (JOVE) Program, Office of University Programs, Goddard Space Flight Center, Greenbelt, Maryland. Stephanie Morris, NOVA University, provided valuable assistance in field collection and transport of coral colonies. The Broward County Office of Natural Resource Protection provided boat time in conjunction with a Florida Sea Grant supported project. We thank G. MullerParker for helpful suggestions on the draft manuscript.

\section{LITERATURE CITED}

Behrenfeld, M., Hardy, J., Gucinski, H., Hanneman, A., Lee, H., Wones, A. (1992). Effects of ultraviolet-B radiation on marine primary production along latitudinal transects in the South Pacific Ocean. Mar. environ. Res. (in press)

Bronikowski, E. J. (1982). The collection, transportation, and maintenance of living corals. In: Ann. Conf. Zool. Parks Aquariums, Phoenix, Arizona

Brown, B. E., Howard, L. S. (1985). Assessing the effects of 'stress' on reef corals. Adv. mar. Biol. 22: 1-63

Chappelle, E. W., Wood, F. W. Jr, McMurtrey, J. E. III, Newcomb, W. W. (1984). Laser-induced fluorescence of green plants. 1. A technique for the remote detection of plant stress and species differentiation. Appl. Optics 23: $134-138$

Coles, S. L., Jokiel, P. L. (1978). Effects of temperature on photosynthesis and respiration in hermatypic corals. Mar. Biol. 43: 209-21.6

Cowles, T. J., Desiderio, R. A., Moum, J. N., Myrick, M., Garvis, D., Angel, M. (1990). Fluorescence microstructure using a laser/fiber optic profiler. SPIE vol. 1302. Ocean Optics X: $336-345$

Cowles, T. J., Moum, J. N., Desiderio, R. A., Angel, S. M. (1989). In situ monitoring of ocean chlorophyll via laserinduced fluorescence backscattering through an optical fiber. Appl. Optics 28(3): 595-600

D'Elia, C. F., Buddemeier, R. W., Smith, S. V. (1991). Workshop on coral bleaching, coral reef ecosystems and global change: Report of Proceedings. Maryland Sea Grant. UM-SG-TS-91-03. University of Maryland. College Park

Goreau, T. J., Macfarlane, A. H. (1990). Reduced growth rate of Montastrea annularis following the 1987-1988 coral bleaching event. Coral Reefs 8: 211-215

Govindjee, G., Papageorgiou, Rabinowitch, E. (1971). Chlorophyll fluorescence and photosynthesis. In: Giose, A. G. (ed.) Photophysiology. Academic Press, New York, p. 1-46

Grigg, R. W., Dollar, S. J. (1990). Effects of natural and anthropogenic disturbance on coral reefs. In: Dubinsky, $Z$. (ed.) Coral reefs. Ecosystems of the world, Vol. 25. Elsevier, New York, p. 439-452

Hardy, J I., Gucinski, H. (1989). Stratospheric ozone depletion: implications for the marine environment. Oceanography, Nov: 18-21

Hayes, R. L., Bush, P. G. (1990). Microscopic observations of recovery in the reef-building scleractinian coral, Montastrea annularis, after bleaching in a Cayman reef. Coral Reefs 8: 203-209

Hayes, R. L., Goreau, T J. (1991). The tropical coral reef ecosystem as a harbinger of global warming. World Resource Review. 3: 306-322

Hoegh-Guldberg, O., Smith, G. J. (1989). Light, salinity, temperature and the population density, metabolism and export of zooxanthellae from Stylophora pistillata and Seriatopora hystrix. J. exp. mar. Biol. Ecol. 129: 279-303

Hoge, F. E. (1986). Active-passive correlation spectroscopy: a new technique for identifying ocean color algorithm spectral regions. Appl. Optics 25(15): 2571-2583

Hoge, F. E., Swift, R. N. (1981). Absolute tracer dye concentration using airborne laser-induced water Raman backscatter. Appl. Optics 20(7): 1191-1202

Hoge, F. E., Swift, R. N. (1983). Airborne dual laser excitation and mapping of phytoplankton photopigments in a Gulf Stream warm core ring. Appl. Optics 22(15): 2272-2281

Hoge, F. E., Swift, R. N. (1985). Airborne mapping of laserinduced fluorescence of chlorophyll a and phycoerythrin 
in a Gulf Stream warm core ring. In: Zirino, A. (ed.) Mapping strategies in chemical oceanography. Advances in Chemistry Series 209. Amer. Chem Soc., Washington, D.C., p. $353-372$

Hoge, F. E., Swift, R. N. (1986), Chlorophyll pigment concentration using spectral curvature algorithms: an evaluation of present and proposed satellite ocean color sensor bands. Appl. Optics 25(20): 3677-3682

Hoge, F. E., Swift, R. N., Yungel, J. K. (1983). Feasibility of airborne detection of laser-induced fluorescence emissions from green terrestrial plants. Appl. Optics 22(19): 2991-3000

Johannes, R. E. (1975). Pollution and degradation of coral reef communities. In: Ferguson Wood, E. J., Johannes, R. E. (eds.) Tropical marine pollution. Elsevier Scientific Publ., Amsterdam, p. 13-50

Jokiel, P. L., Coles, S. L. (1990). Response of Hawaiian and other Indo-Pacific reef corals to elevated temperature. Coral Reefs 8: 155-162

Jokiel, P. L., York, R. H. Jr (1984). Solar ultraviolet photobiology of the reef coral Pocillopora damicornis and symbiotic zooxanthellae. Bull. mar. Sci. 32: 301-315

Kawaguti, S. (1969). Effect of the green fluorescent pigment on the productivity of the reef corals. Micronesica 5: 313 (abstract)

Kim, H. H., Brown, K. S. (1986). Laser and sunlight-induced fluorescence from chlorophyll pigments. Proceedings of IGARSSW 86 Symposium, Zurich $8-11$ Sept. Ref. ESA SP254. IEEE-86CH 2268-1. 3: 1599-1601

Kleppel, G. S., Dodge, R. E, Reese, C. J. (1989). Changes in pigmentation associated with the bleaching of stony corals. Limnol. Oceanogr. 34(7): 1331-1335

Lesser, M. P., Stochaj, W. R., Tapley, D. W., Shick, J. M. (1990). Bleaching in coral reef anthozoans: effects of irradiance, ultraviolet radiation, and temperature on the activities of protective enzymes against active oxygen. Coral Reefs 8 : $225-232$

This article was presented by C. Birkeland, Mangilao, Guam
Logan, A., Halcrow, K., Tomascik, T (1990). UV excitationfluorescence in polyp tissue of certain scleractinian corals from Barbados and Bermuda. Bull. mar. Sci. 46(3): $813-815$

Mazel, C. (1988). Underwater fluorescence. Sea Frontiers Sep-Oct: $274-279$

Morrow, J. H., Murphy, R. C., Booth, C. R. (1991). The feasibility of using natural fluorescence to measure coral productivity. Abstract. XVII Pacif. Sci. Congr. Honolulu, Hawaii, May 27 to June 2

Muscatine, L., Falkowski, P. G., Porter, J. W., Dubinsky, Z. (1984). Fate of photosynthetic fixed carbon in light- and shade-adapted colonies of the symbiotic coral Stylophora pistillata. Proc. R. Soc. Lond. Ser. B. 222: 181-202

Muscatine, L., McClosky, L. R., Marian, R. E. (1981). Estimating the daily contribution of carbon from zooxanthellae to animal respiration. Limnol. Oceanogr. 26 : $601-611$

Nelson, R., Krabill, W. B., Maclean, G. (1984). Determining forest canopy characteristics using airborne laser data. Remote Sensing Environ. 15: 201

Parsons, T. R., Maita, Y., Lalli, C. M. (1988). A manual of chemical and biological methods for seawater analysis. Pergamon Press, New York

Schmuck, G., Lichtenthaler, K. (1986). Application of laserinduced chlorophyll-a fluorescence in the forest decline research. Proceedings, IGARSS 86 Symposium, Zurich, ESA Publication SP-254. IEEE-86CH 2268-1. 3: 1587-1590

Szmant, A. M., Gassman, M. J. (1990). The effects of prolonged 'bleaching' on the tissue biomass and reproduction of the reef coral Montastrea annularis. Coral Reefs 8: $217-224$

Taylor, D. L. (1967). The pigments of the zooxanthellae symbiotic with the intertidal anemone, Anemonia sulcata. J. Phycol. 3: 238-240

Williams, E. H., Bunkley-Williams, L. (1990). Coral reef bleaching alert. Nature 346: 225

Manuscript first received: April 13, 1992

Revised version accepted: July 20, 1992 